\title{
Blood-Lead Monitoring Exposure to Leaded-Gasoline among School Children in Jakarta, Indonesia 2005
}

\author{
Budi Haryanto*
}

\begin{abstract}
Leaded-gasoline has been used as major octane booster of motor vehicles' gasoline in Indonesia since decades ago, except in Jakarta, Batam and Bali where it had not been used from 2001, 2003 and 2004, respectively. Negative effects of lead, such as decreasing of IQ, hearing, growth, and hemoglobin level, then will still be threatening and may continue in the future. Meanwhile, the prolonged lead exposure occurs in the may have more dangerous human health effects to children. The Jakarta blood-lead study in 2001 showed that $35 \%$ elementary school children have blood lead levels (BLLs) more than $10 \mu \mathrm{g} / \mathrm{dl}$, and 2.4\% had BLL more than $20 \mu \mathrm{g} / \mathrm{dl}$ (CDC-USAEP 2001). The objective of this study is to assess the blood lead level of elementary school children in Jakarta urban area in 2005 by evaluating the mean blood lead level of $3^{\text {rd }}$ and $4^{\text {th }}$ grade elementary school children in Jakarta urban area. A cross-sectional survey was implemented to achieve the above objective. The study was conducted in January-February 2005. Portable LeadCare and Hemocue were used to analyze blood-lead and blood hemoglobin $(\mathrm{Hb})$ respectively from children finger blood on site. All of the 20 selected elementary schools agreed to participate in the test. A total of 203 students were allowed by their parents to participate in the test. The overall average for $\mathrm{Hb}$-blood level is $12.6 \mathrm{~g} / \mathrm{dl}$ and for $\mathrm{Pb}$-blood level is $4.2 \mu \mathrm{g} / \mathrm{dl}$. Percentage of those children with Pb-blood equal and more than $10 \mu \mathrm{g} / \mathrm{dl}$ is 1.3\%. The declining Pb-blood prevalence from 2001 study obviously reflects the success of Leaded-gasoline phase-out program in Jakarta. It means that the program is successful in preventing people exposed to leadedgasoline in Jakarta, especially children, from the risk of lead toxicity and its impacts. Thus, the program of phasing-out of leaded-gasoline should be expanded and implemented to all Indonesian provinces and cities in order to avoid lead exposure to people.
\end{abstract}

Key words : Air quality, blood-lead levels, children health effects

\begin{abstract}
Abstrak
Bensin dengan kandungan logam berat timbal digunakan sebagai bahan bakar utama kendaraan bermotor di Indonesia sejak beberapa dekade. Jakarta, Batam dan Bali yang secara berurutan sudah tidak menggunakannya sejak 2001, 2003 dan 2004. Pengaruh negatif logam berat timbal meliputi penurunan tingkat IQ, gangguan pendengaran, gangguan pertumbuhan, dan menurunkan kadar hemoglobin, masih akan terus berlangsung dan mengancam anak-anak. Studi kadar logam berat timbal dalam darah di Jakarta, tahun 2001, menemukan $5 \%$ anak sekolah dasar dengan kadar timbal darah (BLLs) $\geq 10 \mu \mathrm{g} / \mathrm{dl}$, dan 2,4\% mempunyai BLL > $20 \mu \mathrm{g} / \mathrm{dl}$ (CDC-USAEP 2001). Penelitian ini bertujuan menilai kadar timbal darah anak sekolah dasar di Jakarta, tahun 2005. Studi dilakukan pada anak-anak sekolah dasar kelas 3 dan 4 di Jakarta pada periode Januari-Februari 2005. Sebanyak 20 sekolah dasar yang terpilih dan 203 pelajar berartisipasi pada penelitian. Rata-rata kadar hemoglobin darah adalah 12,6 g/dl dan kadar Pb darah adalah 4,2 $\mu$ g/dl. Proporsi anak-anak dengan kadar $\mathrm{Pb}$-darah $\geq 10 \mu \mathrm{g} / \mathrm{dl}$ adalah 1,3\%. Penurunan prevalensi Pb-darah dari studi tahun 2001 secara meyakinkan merefleksikan keberhasilan program penghapusan bensin bertimbal di Jakarta. Itu berarti bahwa program tersebut berhasil mencegah pajanan risiko toksik dan dampak kesehatannya pada penduduk Jakarta, khususnya anak-anak. Program penghentian bahan bakar bertimbal disarankan untuk diperluas pada seluruh provinsi dan kota di Indonesia. Kata kunci : Kualitas udara, kadar timbal $(\mathrm{Pb})$ darah, dampak kesehatan pada anak-anak
\end{abstract}

*Staf Pengajar Departemen Kesehatan Lingkungan Fakultas Kesehatan Masyarakat Universitas Indonesia 
Rapid growth of urbanization and industrialization in Indonesia has created severe air pollution problems, particularly in major cities. The United Nations Environmental Program ranks Jakarta as the world's third most polluted mega-city, after Mexico and Bangkok. Vehicular traffic emissions are obvious and major sources of air pollution. An ADB-funded regional Technical Assistance estimated that vehicle emissions in Jakarta amount to approximately $71 \%$ of the oxides of nitrogen $\left(\mathrm{NO}_{\mathrm{X}}\right), 15 \%$ of sulfur dioxide $\left(\mathrm{SO}_{2}\right)$, and $70 \%$ of particulate matter $\left(\mathrm{PM}_{10}\right)$ in the total emission loads, and the annual economic cost of the associated health problems will be about $\$ 450$ million by $2015 .{ }^{1}$ The World Bank study ${ }^{2}$ estimated health damage due to all sources of air pollution in Jakarta at approximately $\$ 300$ million per year in 1990, and this was projected to increase by tenfold by 2010 unless serious control efforts were implemented. Total population in DKI Jakarta is expected to grow from approximately 9.5 million in 1998 to 11 million in 2005, and to 13 million in 2015.

In Indonesia, except in Jakarta-the capital city, lead $(\mathrm{Pb})$ is still being used in many products and especially as octane booster for gasoline. This means that the negative effects of lead, such as decreasing in IQ, hearing, growth, and hemoglobin content will still be occurring and will continue in the future. The efforts to eliminate effects of environment lead exposure from gasoline had been starting in Jakarta City by replacing leaded gasoline to unleaded gasoline since July $1^{\text {st }}, 2001$ and will continue to all of provinces in Java Island (the most populated island with about $60 \%$ of Indonesia population) in the year of 2002 , and finally to all of Indonesia provinces by the year of 2003 for the first scenario, and by the year 2005 for the last scenario. However, the plan seems very difficult to be implemented on time due to political issues and lack of government willingness rather than the economic problems. Meanwhile, the longer lead exposure occurs in the environment the more dangerous the health effects especially to the children will be.

The human health impacts of exposure to environmental lead have been extensively researched overseas for many years as well as studies on the respiratory diseases caused by air pollution. Progressive studies have shown these impacts to occur at progressively lower levels of exposure, such that it is now considered by the majority of health scientists that there is no threshold level below which these effects do not occur. ${ }^{3}$ It is regarded to be one of the most serious health problems facing populations, particularly children. Common symptoms include IQ loss, reading and learning difficulties, hearing loss, difficulties in concentration, adverse on kidney function effects, blood chemistry, and the cardiovascular system as well as adverse reproductive effects for women. The negative impacts of lead pollution on human health are well documented. ${ }^{4}$ The most usual indicator of human exposure to environmental lead is the amount that can be measured in blood. 5 The World Health Organization has set a standard for the maximum acceptable blood lead level at 20 micrograms per deciliter and the Center for Diseases Control and Prevention USA suggested children blood lead level is not exceed of 10 micrograms per deciliter. ${ }^{6,7}$ However, more recent studies have shown measurable and chronic health effects at much lower levels. Exposure is primarily caused by airborne lead. In congested urban areas, exhaust fumes from vehicles using leaded gasoline typically account for some 90 percent of airborne lead pollution. ${ }^{8}$

Several studies related to blood-lead level conducted in Jakarta found that the average of Jakarta public bus drivers' blood-lead was $24.6 \mu \mathrm{g} / \mathrm{dl}$ in $1978 .{ }^{9}$ A 1991 study on Jakarta residents showed such levels to be typical ranging to be over than $30 \mu \mathrm{g} / \mathrm{dl}$ in some sections of the population. In particular, $74 \%$ of 66 slum dwellers, who live and work in heavily trafficked areas, had blood lead level $>30 \mu \mathrm{g} / \mathrm{dl} .{ }^{10}$ The 2001 blood-lead study among elementary school children showed $35 \%$ had blood lead level (BLL) more than $10 \mu \mathrm{g} / \mathrm{dl}$, and 2.4\% had BLL more than $20 \mu \mathrm{g} / \mathrm{dl} .{ }^{11}$ Other study in Bandung city shows similar trend, $50 \%$ of street vendors having blood-lead levels above $40 \mu \mathrm{g} / \mathrm{dl} .^{12}$ It might be concluded, then, that significant chronic health impacts are caused in many sections of the population in Jakarta, by chronic exposure to environmental lead, and that the major source is lead in gasoline.

The lack of evidence from epidemiological studies, concerning lead and dust air pollution to people's health effects in Jakarta, is believed as a potential reason that may affects to the lack of awareness and willingness of public policy decision makers to develop appropriate strategy for preventing Jakarta population from the hazards of air pollution. Therefore, the study providing information in epidemiological evidences of children health effects caused by air pollution in Jakarta is needed and very important to be conducted.

The objectives of the studies are to assess the blood lead level patterns of elementary school children in Jakarta urban area 2005.

\section{Methods}

A cross-sectional survey was implemented for assessing the blood lead level patterns of school children in Jakarta city in 2005 . The study population was the $3^{\text {rd }}$ and $4^{\text {th }}$ grade children who attend school in Jakarta. Children were studied because they are the age group that is most vulnerable to health damage from lead and air pollution dust. It is also not feasible to examine all primary school grades because of time and logistic considerations. Four (4) elementary schools selected ran- 
domly from surroundings of every single of 5 ambient monitoring stations near the roads in Jakarta urban area were involved in this study. The 5 ambient monitoring stations are located in: Jasa Marga Office (East Jakarta), EMC-Puspiptek Serpong (Banten), Taman Anggrek Lebak Bulus (South Jakarta), Hotel Indonesia (Central Jakarta), and Trisakti University (West Jakarta).

Given the size of Jakarta in terms of both population ( 12 million) and geography, a simple random sample at the household level was not considered to be logistically feasible. Therefore, a cluster survey design was used for the cross-sectional study. Clusters were defined as elementary schools in five selected air monitoring stations in Jakarta. Four elementary schools nearest every single of the monitoring station are assigned as clusters. Thus, 20 elementary schools will be the source of sample (children). An equal probability random sample of $10,3^{\text {rd- }}$

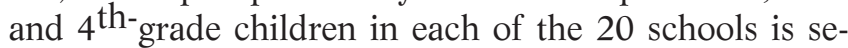
lected for inclusion in the study. The number of sample is 200 elementary school children. Sample size was calculated to provide large enough sample so that the margin of error around the mean $(95 \% \mathrm{CI})$ was $\pm 10 \%$ accounting for clustering. Based on prevalence from the previous study result conducted by CDC in 2001, the number of sample from cluster sampling design calculation is 200 .

There were 5 study teams each consisting of 6 people (30 people total): Each team includes the following: 1 phlebotomist, 3 interviewers, 1 person to handle all paperwork (consent forms, results sheets, labeling of blood sample), and 1 CHR-UI (Center for Health ResearchUniversity of Indonesia) supervisor. Consent forms and questionnaires distributed to school principals in the selected schools prior to the beginning of the study. The principals asked to send the forms home with the children so that the parents can fill them out and return them to the schools with their children before the CHR-UI team arrives.

Letters are generated to inform parents of their children's blood-lead test results and these will be given to each school principal for distribution 1-3 days after the sample has been collected. The blood samples are tested using the LeadCare portable analyzer. ${ }^{13}$ The procedure involves placing the sample into a reagent tube and allowing it to rest for at least 1-2 minutes, followed by placing the sample onto the LeadCare electrode. The analyzed result is available in 3 minutes. Because the upper end of the operational range for the LeadCare analyzer is $95^{\circ} \mathrm{F}$ and ambient temperatures in Jakarta was higher than that, the CHR-UI team analyzed the bloods in air conditioned rooms in the evenings. Blood specimens do not stored after analyses are completed. Instead, all excess bloods and used materials (lancets, tubes, swabs, wipes, and gloves) are collected in bio- hazard bags and taken for biohazard disposal. The duration of the study is 6 months and started at January 2005 to June 2005, including study preparation, materials development, field preparation, data collection, data analyses, interim report writing, report improvement, and seminar of findings.

\section{Results}

All of the 20 selected elementary schools agreed to participate the test. Totally, a number of 203 students (third and fourth graders) are allowed by their parents participate the test. Unfortunately, about $5 \%$ of the blood samples (11 students) could not be analyzed. A number of 144 subjects in Jakarta area are included in the analysis.

The average of blood lead levels (BLLs) in South Jakarta is $5.1 \mu \mathrm{g} / \mathrm{dl}$, the average of BLLs in East Jakarta is $4.4 \mathrm{mg} / \mathrm{dl}$, the average of BLLs in Central Jakarta is 4.6 $\mu \mathrm{g} / \mathrm{dl}$, and the average of BLLs in West Jakarta is 2.4 $\mu \mathrm{g} / \mathrm{dl}$. Overall, the average for Hb-blood levels is 12.6 $\mathrm{g} / \mathrm{dl}$ and for BLLs is $4.2 \mu \mathrm{g} / \mathrm{dl}$. Those children with BLLs equal and more than $10 \mu \mathrm{g} / \mathrm{dl}$ is $1.3 \%$.

Transportation used by subjects to access school is varies. Most of subjects (about 65\%) reported just take a walk (mean of BLLs is $4.6 \mu \mathrm{g} / \mathrm{dl}$ ), followed by using motorcycle ( $19 \%$ with mean of BLLs is $3.9 \mu \mathrm{g} / \mathrm{dl})$, using car $(10 \%$ with mean of BLLs is $4.7 \mu \mathrm{g} / \mathrm{dl})$ and using bicycle (6\% with mean of BLLs is $7.5 \mu \mathrm{g} / \mathrm{dl})$. ANOVA test for BLLs shows significant difference with $\mathrm{p}$-value = 0.006 for bicycling and walking, bicycling and motorcycling, and bicycling and car. While others were found to be non-significant (Tukey HSD ANOVA test).

Duration on the way during accessing school shows that most of subjects (about 62\%) reported spent 5 to 15 minutes (mean of BLLs is $4.5 \mu \mathrm{g} / \mathrm{dl}$ ), followed by those who spent less than 5 minutes ( $23 \%$ with mean of BLLs is $4.7 \mu \mathrm{g} / \mathrm{dl})$, those who spent 16 to 30 minutes $(13 \%$ with mean of BLLs is $5.4 \mu \mathrm{g} / \mathrm{dl}$ ) and those who spent more than 30 minutes (3\% with mean of BLLs is 4.5 $\mu \mathrm{g} / \mathrm{dl})$. ANOVA test for BLLs shows non-significant result $(\mathrm{p}$-value $=0.56)$.

Distance of home to school from the data revealed that most of subjects (about $41 \%$ ) reported the distance of $200 \mathrm{~m}$ to $500 \mathrm{~m}$ (mean of BLLs is $4.6 \mu \mathrm{g} / \mathrm{dl}$ ), followed by those with the distance of less than $200 \mathrm{~m}(26 \%$ with mean of BLL is $5.0 \mu \mathrm{g} / \mathrm{dl}$ ), those with the distance of 501 $\mathrm{m}$ to $1.000 \mathrm{~m}(20 \%$ with mean of BLLs is $4.4 \mu \mathrm{g} / \mathrm{dl})$ and those with the distance of further than $1 \mathrm{~km}(13 \%$ with mean of BLLs is $4.2 \mu \mathrm{g} / \mathrm{dl}$ ). ANOVA test for BLLs shows non-significant result ( $\mathrm{p}$-value $=0.69$ ).

The results from those outside Jakarta (40 subjects in Serpong subdistrict) show overall average for hemoglobin is $12.8 \mathrm{~g} / \mathrm{dl}$ and for BLLs is $9.0 \mu \mathrm{g} / \mathrm{dl}$. Those children with BLLs equal and more than $10 \mu \mathrm{g} / \mathrm{dl}$ is $26.8 \%$. 


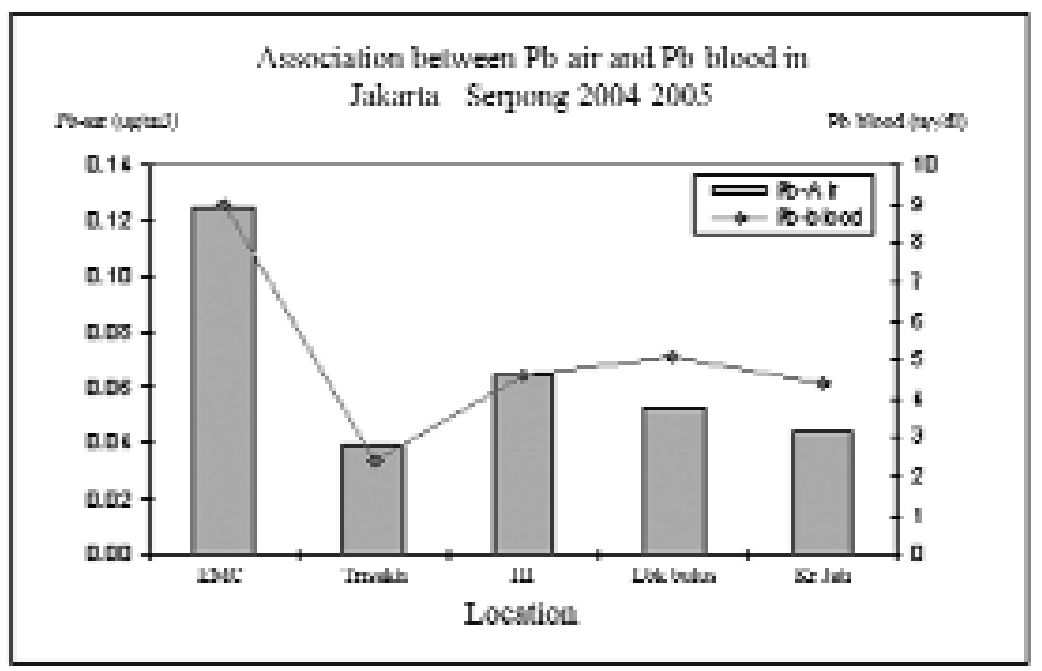

Figure 1. Association of Pb-air average concentration (Jan-Sep'04) and student's BLLs (March'05) in Jakarta

\section{Discussion}

Subjects with bicycle found to have highest average of $\operatorname{BLL}(7.5 \mu \mathrm{g} / \mathrm{dl})$ among other modes of transportation who has average below $5.0 \mu \mathrm{g} / \mathrm{dl}$. If the main source of $\mathrm{Pb}$ exposure is from motor vehicle traffics, it seems that frequency and capacity of lung of subjects using bicycle is likely to be higher in inhaling Pb-ambient. Meanwhile, duration to go to school from home vice versa and the distance of school from home have no any association to the average of BLLs among subjects. It means that contact to $\mathrm{Pb}$-ambient is happened at anytime and anywhere among the subjects.

The CDC-USAEP's Pb-blood study among 396 elementary school children in Jakarta in 2001 found that geometric means of Pb-blood children levels is $8.6 \mu \mathrm{g} / \mathrm{dl}$. About $35 \%$ of the children having Pb-blood levels exceed $10 \mu \mathrm{g} / \mathrm{dl} .^{8}$ Meanwhile, this study found Pb-blood levels means $4.2 \mu \mathrm{g} / \mathrm{dl}$ and $1.3 \%$ children with Pb-blood levels is above $10 \mu \mathrm{g} / \mathrm{dl}$. The different of BLLs prevalence of $35 \%$ in 2001 and $1.3 \%$ in 2005 obviously shows the success of certain intervention within the years.

\section{Conclusion}

Overall, the average for Hb-blood levels is 12.6 $\mathrm{mmHg}$ and for BLLs is $4.2 \mu \mathrm{g} / \mathrm{dl}$. The highest average of BLLs is in South Jakarta $(5.1 \mu \mathrm{g} / \mathrm{dl})$ and the lowest is in West Jakarta $(2.4 \mu \mathrm{g} / \mathrm{dl})$. Those children with BLLs equal and more than $10 \mathrm{mg} / \mathrm{dl}$ is $1.3 \%$. Based on transportation used by subjects to access school, the highest average of BLLs is using bicycle (6\% with mean of BLLs $7.5 \mu \mathrm{g} / \mathrm{dl})$ and the lowest using motorcycle (19\% with mean of BLLs $3.9 \mu \mathrm{g} / \mathrm{dl}$ ). ANOVA test for BLLs shows significant difference with $\mathrm{p}$-value $=0.006$ for bicycling and walking, bicycling and motorcycling, and bicycling and car. Based on duration on the way during accessing school shows that the longer the duration the higher the mean of BLL. Subjects reported spent 5 to 15 minutes (mean of BLLs $4.5 \mu \mathrm{g} / \mathrm{dl}$ ), those who spent less than 5 minutes (mean of BLL $4.7 \mu \mathrm{g} / \mathrm{dl}$ ), those who spent 16 to 30 minutes (mean of BLL $5.4 \mu \mathrm{g} / \mathrm{dl}$ ) and those who spent more than 30 minutes (mean of BLL $4.5 \mu \mathrm{g} / \mathrm{dl}$ ). ANOVA test for BLLs shows non-significant result (pvalue $=0.56$ ). Based on distance of home to school reported the distances, there is no specific trend of mean of BLL. The highest is the distance of less than $200 \mathrm{~m}$ (mean of BLL $5.0 \mu \mathrm{g} / \mathrm{dl}$ ), the lowest is the distance of farther than $1 \mathrm{~km}$ (mean of BLLs $4.2 \mu \mathrm{g} / \mathrm{dl}$ ). ANOVA test for BLLs shows non-significant result $(\mathrm{p}$-value $=$ $0.69)$.

\section{Recommendation}

Compare to the Jakarta Blood-lead Study in 2001, it was showed that $35 \%$ elementary school children have blood lead levels (BLLs) more than $10 \mathrm{mg} / \mathrm{dl}$, and $2.4 \%$ had BLLs more than $20 \mathrm{mg} / \mathrm{dl}$ (CDC-USAEP 2001). The declining Pb-blood prevalence from 2001 study obviously reflects the success of Leaded-gasoline phase-out program in Jakarta. It means that the program is successful in preventing people exposed to leaded-gasoline in Jakarta, especially children, from the risk of lead toxicity and its impacts. Thus, the program of phasing-out of leadedgasoline should be expanded and implemented to all Indonesian provinces and cities in order to avoid lead exposure to people. 


\section{Reference}

1. ADB. 2000. Technical Assistance for Action Plans for Reducing Vehicle Emissions. Manila.

2. World Bank.1994. Report No 12083-IND: Indonesia Environment and Development: Challenges for the Future. Washington.

3. CDC (November, 1997). Screening young children for lead poisoning: guidance for state and local public health officials, U.S. Department of Health and Human Services, Public Health Service.

4. CDC (1991). "Preventing Lead Poisoning in Young Children: A Statement by the Centers for Disease Control.” Report No. 99-2230, Atlanta, GA: CDC, US Department of Health and Human Services, 1991.

5. WHO (1987). Air Quality Guidelines for Europe. Geneva, WHO Publications.

6. CDC (1997). Screening young children for lead poisoning: guidance for state and local public health officials, U.S. Depart. of Health and Human Services, Public Health Service.

7. WHO (1995). Inorganic Lead. Geneva, WHO.
8. Haryanto, B. (2003). "Gasoline Health Effects: Considerations for Public Policy Development.” Proceeding of ENVIROTECH-2003 Regional Workshop on Integrated Vehicle Emission Reduction Strategy, Jakarta, October 2003

9. Achmadi, UF, et al (1978). "Kadar timbal darah pengemudi bis, taksi, dan bajaj di Jakarta 1978 ” Majalah Widiapura, Jakarta, 1978

10. Fardiaz, S. (1992). Polusi Air dan Udara, Penerbit Kanisius Yogyakarta

11. Albalak R, Noonan G, Kim D, Buchanan S, Blumenthal W, et al.(2001). Lead Exposure and Anemia among Children in Jakarta, Indonesia. Report. Center for Disease Control and Prevention in collaboration with the United States Environmental Protection Agency

12. Haryanto, B. (1993). Profil Pb Dalam Darah Perokok yang Bekerja di Daerah Padat Lalu Lintas di Kotamadya Bandung Tahun 1992. Tesis. Jurusan Kesehatan Lingkungan FKM. Depok, Universitas Indonesia.

13. Zink, E., Cullison, J., Bowers, ML., Wegner, SE., Naser, N., O’Daly, J., et al. (1997). Review of the performance characteristics of the LeadCare blood lead testing system, ESA Inc. 1997. 